\title{
Extracellular Cold Active Alkaline Proteolytic Enzyme Produced By Pseudomonas gessardii Strain N-86 Isolated from Antarctica
}

\author{
Abhas Kumar Maharana ${ }^{1,2} *$ and Shiv Mohan Singh ${ }^{1,3}$ \\ ${ }^{1}$ Polar Biology Laboratory, National Centre for Antarctic \& Ocean Research, \\ Vasco-da-Gama, Goa-403804, India \\ ${ }^{2}$ Water Quality Management Division-II, Central Pollution Control Board, \\ Parivesh Bhawan, East Arjun Nagar, Delhi-110032, India \\ ${ }^{3}$ Department of Botany, Institute of Science, \\ Banaras Hindu University, Varanasi-221005, India \\ *Corresponding author
}

\section{A B S T R A C T}

\begin{tabular}{|c|}
\hline Keywords \\
\hline $\begin{array}{l}\text { Cold adapted, East } \\
\text { Antarctica, } \\
\text { Larsemann Hills, } \\
\text { Nella Lake, } \\
\text { Protease, } \\
\text { Psychrotolerant, } \\
\text { Sediment core }\end{array}$ \\
\hline Article Info \\
\hline $\begin{array}{l}\text { Accepted: } \\
21 \text { May } 2020 \\
\text { Available Online: } \\
10 \text { June } 2020\end{array}$ \\
\hline
\end{tabular}

\section{Introduction}

Proteases are the hydrolytic enzymes that act up on different kinds of proteins lead to formation of smaller peptides and amino acids. On the basis of action it is of exo- or
To produce cold active protease, investigation was conducted using bacteria isolated from the core sample of Nella Lake, East Antarctica. Isolates were screened for protease using plate assay method followed by submerged fermentation at cold temperature. Potential isolate was identified as Pseudomonas gessardii strain N-86 by molecular technique. Further, investigations were performed to enhance the protease production capabilities by submerged fermentation technique using strain $\mathrm{N}-86$ with various physiological (temperature and $\mathrm{pH}$ ) and chemical (Carbon, nitrogen, minerals, amino-acids, and various substrates) parameters. Production optimization revealed the maximum protease production by using skim milk $(2 \% \mathrm{w} / \mathrm{v}), \mathrm{pH} 9.5$ and $10 \% \mathrm{v} / \mathrm{v}$ of inoculum size at $15^{\circ} \mathrm{C}$. Additional potential inducers for protease production were sucrose $(1 \% \mathrm{w} / \mathrm{v}), L$-Glutamine $(0.01 \% \mathrm{w} / \mathrm{v})$ and $\mathrm{MgCl}_{2}(0.1 \% \mathrm{w} / \mathrm{v})$. Final productions with optimized conditions gave 5.42 -fold increase in protease production on $72 \mathrm{~h}$ of incubation. The present study successfully produced cold-active protease which may have novel properties to degrade protein based wastes which can contribute in cleaning of environment at cold regions without harming the climate and also can be used in various detergent, textile, food and beverage industries effectively. The present study is the first report on Pseudomonas gessardii isolated from Nella Lake, Antarctica producing cold active protease. 
proteases (Maharana et al., 2016). Proteases can be found in almost all kingdom viz. Animalia, Plantae, Fungi, Bacteria, Archaea and even in viruses. However, microbial origin proteases are preferred due to diversified uses and compatibility. Microbial proteases have immense applications as compared to other hydrolytic enzymes in various spheres of science and industries. Alkaline proteases are one of the most important groups of enzymes, used in various industrial products and processes as detergents, pharmaceuticals, leather, meat tenderizers, protein hydrolyzates, food products and even in the waste processing (Sen et al., 2009).

Cold active enzymes are in high demand in various food and beverages, detergent and textile industries and to fill this huge requirement, it is necessary to investigate on cold active microorganisms capable of producing cold enzymes (Maharana, 2016). Enzymes from psychrotolerants are more adaptable than mesophiles and psychrophiles due to their wider range of temperature stability, and which can be used for bioremediation and wastewater treatments at cold regions (Maharana and Ray, 2015a).

Huang et al., (2016) isolated Pseudomonas gessardii strain LZ-E from wastewater discharge site of a petrochemical company of Lanzhou city which showed degradation capabilities of naphthalene and hexavalent chromium. The production of enzymes depends on many physical and chemical variables which control the production by regulating the growth of isolates used in the processes and optimization is necessary for the hyper production of any enzymes before doing large-scale production (Maharana and Ray, 2015b).

Pseudomonas spp. is well known for production of lipase enzymes which may be of cold or mesophilic (Gao et al., 2000; Rashid et al., 2001; Maharana and Ray, 2014c; Maharana and Ray, 2015a). Some reports are available showing Pseudomonas spp. having potentiality to produce proteases at low temperatures (Hamamoto et al., 1994; Vazquez et al., 2002; Baghel et al., 2005; Reddy et al., 2009; Maharana and Ray, 2013; Singh et al., 2014, 2015; Caldera et al., 2016; Matsui et al., 2017). Besides, cold active proteases were well produced by psychrotolerant fungi (Singh et al., 2012b; Maharana and Ray, 2014a; Maharana and Ray, 2014b).

Lake Nella $\left(76^{\circ} 22^{\prime} \mathrm{S}, 6^{\circ} 24^{\prime} \mathrm{E}\right)$, an ultraoligotrophic lake is located at an altitude of $15 \mathrm{~m}$ a.s.1. in the Broknes peninsula, Larsemann Hills region, East Antarctica. The lake holds fresh to slightly saline waters and has high possibilities of getting cold microorganisms which in turn have many potential applications to various sectors of science. As microbiological study is concerned, Nella Lake is not yet much explored except studies from Singh et al., (2017) and Maharana and Singh, (2018 a,b,c) where cold active enzymes like lipase and amylase were explored from bacterial and fungal isolates. There was no study performed on cold active proteases in that habitat; therefore, one approach was taken in the present study to produce cold active extracellular protease from microbes isolated from sediment cores of Nella Lake using a psychrotolerant bacteria i.e. Pseudomonas gessardii strain N-86.

\section{Materials and Methods}

\section{Chemicals, reagents and instruments}

The chemicals and reagents were of analytical grade (Hi-Media laboratories, Mumbai, India; Bangalore Genei, India; Sigma Aldrich Chemicals Private Limited, Bengaluru, 
Karnataka, India). Instruments used were microscope (Epi-fluorescence research microscope, BX51 Olympus, Japan), $-20^{\circ} \mathrm{C}$ freezer (Biomedical freezer, MDF-U537D, Sanyo), low temperature static incubator (MIR 253 \& MIR-554-PE, Sanyo, Japan), refrigerated incubator shaker (IS-971RF, Jeio tech, Korea), pH analyzer (Orion 930, Thermo Electron, USA), refrigerated table top centrifuge (5810, Eppendorf, Germany), refrigerated circulatory water bath (F25-MC, Julabo, Germany) and UV-Vis spectrophotometer (Specord S205, Analytik Jena, AG Germany) etc.

\section{Sampling and isolation of bacteria}

Microorganisms investigated in this present study were isolated from the sediment core samples of Lake Nella in the Broknes peninsula, Larsemann Hills region, East Antarctica. Core samples were serially diluted by 10 -fold dilution technique and spread over various media viz. Antarctic Biological Medium (ABM), ABM/10 and Nutrient Agar (NA), NA/10 for isolation of bacteria.

Plates were incubated for 1-2 weeks at 1, 5, 15 and $22^{\circ} \mathrm{C}$ and after visible, cultures were streaked on the same agar plate for further purification microscopically. Purified isolate was stored at $-20^{\circ} \mathrm{C}$ with $20 \%$ glycerol (v/v) and $1 / 10^{\text {th }}$ dilution of nutrient broth. This culture was revived from glycerol stock by spreading on the same isolation agar medium and multiple copies were also made and stored at $4^{\circ} \mathrm{C}$ for further use.

\section{Screening for cold active protease}

Isolates were investigated qualitatively by spot inoculation method on skim milk agar (Hi-media) by incubating respective plates at 4, 15 and $22^{\circ} \mathrm{C}$. Hydrolytic zone diameters were calculated by subtracting the whole diameter to that of bacterial colony diameter.
Potent enzyme producers were selected on the basis of maximal zone of clearances.

\section{Production strategies for cold active protease}

Those isolates again investigated for quantitative screening to select best isolate for cold active extracellular protease production. For this potential isolates were inoculated in nutrient broth (Hi-media) and incubated for 2 days at $15^{\circ} \mathrm{C}$ with $150 \mathrm{rpm}$. From that about $5 \%(\mathrm{v} / \mathrm{v})$ inoculum was taken in protease production medium (g.L ${ }^{-1}: \mathrm{NaCl}, 2 ; \mathrm{CaCl}_{2}$, $0.1 ; \mathrm{MgSO}_{4}, 0.4 ; \mathrm{K}_{2} \mathrm{HPO}_{4}, 0.3 ; \mathrm{KH}_{2} \mathrm{PO}_{4}, 0.3$; $\left(\mathrm{NH}_{4}\right)_{2} \mathrm{SO}_{4}, 0.5$; casein, $\left.10 ; \mathrm{pH}, 7\right)$ and incubated at $15^{\circ} \mathrm{C}$ with $150 \mathrm{rpm}$ for $96 \mathrm{~h}$.

Crude enzyme (supernatant) was collected by centrifugation of production medium at $12,000 \mathrm{rpm}$ at $4^{\circ} \mathrm{C}$ for $20 \mathrm{~min}$. For production purposes freshly prepared inoculum of isolates were used. Two steps selection procedure were adopted to select one best bacterial isolate for further study. The potent isolate was outsourced for $16 \mathrm{~S}$ rDNA gene sequencing for identification in molecular level.

\section{Protease assay}

The quantitative assay of the protease activity was performed using a modified method of Park et al., (2014). One $\mathrm{ml}$ of crude enzyme was incubated with $0.65 \%$ casein solution (prepared with $0.05 \mathrm{M}$ phosphate buffer, $\mathrm{pH}$ 7.0) for $10 \mathrm{~min}$ at $15^{\circ} \mathrm{C}$ in water bath. Reaction was stopped by adding $5 \mathrm{ml}$ of 110 $\mathrm{mM}$ Tri-chloro acetic acid (TCA) and incubated for $30 \mathrm{~min}$.

It was then centrifuged at $12,000 \mathrm{rpm}$ at $4^{\circ} \mathrm{C}$ for $5 \mathrm{~min}$. and about $5 \mathrm{ml}$ sodium carbonate $(500 \mathrm{mM})$ followed by $1 \mathrm{ml}$ Folin reagent was added. Respective enzyme blanks were also made by eliminating the incubation period. 
The absorbance at $660 \mathrm{~nm}$ was measured, and the amount of tyrosine released from casein was calculated using a standard curve for $L$ tyrosine. One unit of enzyme activity was defined as the amount of enzyme that released $1 \mu \mathrm{g}$ of tyrosine per minute under assay conditions.

\section{Production optimization for proteolytic degradation}

Production optimization for protease was done using submerged fermentation technique by "one factor at-a-time" (OFAAT) method. Factors investigated were various substrates, incubation temperature, initial medium $\mathrm{pH}$, substrate concentrations, nitrogen and carbon sources, amino acids, minerals, inoculum size, and incubation period. In each experiment, the optimized factor was integrated with the control medium in triplicates. Besides, one control in every production was also considered in each step devoid of supplied factors for comparative selection among the parameters. After optimization final protease production was done using optimized conditions.

\section{Statistical analysis}

The data recorded during the investigation were subjected to significance test by t-test and analysis of variance (ANOVA). Statistical significance was set at $p<0.05$, and for high significance set at $p<0.001$. Results were denoted as mean \pm standard error (SE) of triplicate experiments.

\section{Results and Discussion}

Screening and selection for cold active protease producers

A total of 178 bacteria were isolated at various temperatures. All isolates were investigated for protease production qualitatively by plate assay method at various temperatures i.e. 4,15 and $22^{\circ} \mathrm{C}$. Almost 90 isolates $(50.56 \%)$ showed positive for protease at $4{ }^{\circ} \mathrm{C}$ while 96 isolates $(53.93 \%)$ showed positive at both 15 and $22^{\circ} \mathrm{C}$. Some of isolates showing positive for protease on skim milk agar plates are depicted in Figure 1.

Among them potential fifteen (15) isolates were selected on basis of zone of clearances for further quantification using casein as substrate at $15^{\circ} \mathrm{C}$ and incubated for $96 \mathrm{~h}$. Figure 2 denotes protease production by those 15 potential isolates.

For final selection best four (4) isolates were chosen and investigated using two substrates i.e. skim milk and casein, which were investigated day-wise (Fig. 3). It reveals maximum production was achieved by strain $\mathrm{N}-86$ on $2^{\text {nd }}$ day of incubation at $15^{\circ} \mathrm{C}$. Therefore, from onwards N-86 was taken as potent isolate for protease production. The N86 was outsourced and identified as Pseudomonas gessardii strain N-86 (GenBank accession no. KY783362), which is a Gram negative and rod shaped bacterium. ANOVA reveals that the differences in protease activity due to various bacteria w.r.t. two substrates are highly significant $(p<0.001)$.

Production optimization of protease using Pseudomonas gessardii strain N-86

\section{Effects of incubation temperature}

Various temperatures viz. 5, 10, 15, 25, 30, 35 and $45^{\circ} \mathrm{C}$ were investigated for protease production using strain N-86. Pseudomonas gessardii strain N-86 showed maximum protease production by incubation temperature of $15^{\circ} \mathrm{C}$ and after this there is a gradual decrease in production (Fig. 4). It showed a possibility of getting an enzyme that can be active at a lower temperature. 
The effect of incubation temperature on protease production is significant as per ANOVA test at $p<0.01$. The t-stat also shows a significant difference between their population mean at 0.01 probability level.

\section{Effects of initial pH}

Initial $\mathrm{pH}$ of the production medium was set at various $\mathrm{pH}$ ranging from 4.5-11.5, while production of protease was more at alkaline range than acidic and optimum $\mathrm{pH}$ was 9.5 (Fig. 5). There is a positive and high significant correlation found among the initial $\mathrm{pH}$ of the medium and protease activity $(\mathrm{r}=$ $0.914)$ at $p<0.001$ which denotes with an increase in $\mathrm{pH}$ of the medium, protease production increases. Significance is again confirmed by the t-test even at population level at $p<0.001$. ANOVA test reveals that there is a high significant difference between the effects of initial $\mathrm{pH}$ of the medium on protease production at 0.001 probability level.

\section{Effects of substrate concentrations}

It is confirmed from Figure 3 that, the maximum protease activity was found by using skim milk as substrate. Therefore, various concentration of skim milk was further investigated at concentration of 0 , $0.25,0.5,1.0,1.5,2.0$ and $2.5 \%(w / v)$. Figure 6 reveals maximum protease production at a skim milk concentration of $2.0 \%(\mathrm{w} / \mathrm{v})$.

There is a positive and significant correlation found among the initial $\mathrm{pH}$ of the medium and protease activity $(\mathrm{r}=0.936)$ at $p<0.01$ which denotes with an increase in concentration of skim milk, protease production increases. Significance is again confirmed by the t-test even at population level at $p<0.05$. ANOVA test reveals that there is a significant difference between the effects of substrate concentrations on protease production at 0.05 probability level.

\section{Effects of nitrogen sources}

Various organic nitrogen sources like Yeast Extract, Beef Extract, Peptone and in-organic nitrogen sources like $\mathrm{NaNO}_{3}, \mathrm{KNO}_{3}$ and $\mathrm{Ca}\left(\mathrm{NO}_{3}\right)_{2} \cdot 4 \mathrm{H}_{2} \mathrm{O}$ at a concentration of 0.5 and $1.0 \%(\mathrm{w} / \mathrm{v})$ were taken for investigation. But, there is no significant production found by using these nitrogen sources as compared with the previous control medium. This might be due to the presence of nitrogen source in the form of skim milk in the medium, which was self-sufficient for the productions of protease using strain N-86.

\section{Effects of carbon sources}

Various carbon sources like Xylose, Fructose, Lactose, Maltose, Glucose and Sucrose at a concentration of $1.0 \%(\mathrm{w} / \mathrm{v})$ were taken for investigation with a control medium having previous optimized medium. Among all the carbon sources Sucrose $(1 \%$ w/v) was regarded as the potential carbon source which induce strain $\mathrm{N}-86$ for more production of protease at $15^{\circ} \mathrm{C}$ (Fig. 7). ANOVA reveals a high significant differences among the carbon sources used at $p<0.001$.

\section{Effects of amino-acids}

Various amino acids as indicated in Figure 8 at a concentration of $0.01 \%(\mathrm{w} / \mathrm{v})$ were taken for investigation with a control medium having previous optimized medium, which devoid of any amino acids. Among 20 amino acids $\quad L$-Serine, $L$-Phenylalanine, $\quad L$ Methionine, $L$-Histidine, $L$-Glutamine and $L$ Ascorbic acid were regarded as inducers for protease production by strain N-86.

However, maximum production of protease was observed using L-Glutamine. ANOVA reveals a high significant differences among the amino acids for production of protease at $p<0.001$. 


\section{Effects of minerals}

Among the eleven (11) mineral chlorides as depicted in Figure 9, only three have inductive effect for the protease production i.e. $\mathrm{KCl}, \mathrm{MgCl}_{2}$ and $\mathrm{CaCl}_{2} . \mathrm{MgCl}_{2}$ showed maximum protease activity w.r.t. control. ANOVA reveals a high significant differences among the mineral chlorides for protease production at $p<0.001$.

\section{Effects of inoculum size}

Inoculum sizes of $01,0.5,1.0,2.5,5.0,10$ and $20 \%(\mathrm{v} / \mathrm{v})$ were taken for investigation. Maximum production was found at $10 \% \mathrm{v} / \mathrm{v}$ of strain N-86 using skim milk as substrate (Fig. 10). The t-test reveals that there is a significant variation among the population means of protease activity with respect to varied inoculum sizes at $p<0.05$.

\section{Effects of incubation period}

After all parameters investigated final protease production was done using optimized conditions for $168 \mathrm{~h}$ (Fig. 11). Maximum protease production of $1.414 \mathrm{U} / \mathrm{ml}$ was achieved on $72 \mathrm{~h}$ of incubation at $15^{\circ} \mathrm{C}$, which was 5.42 fold increases in protease production as compared with the un-optimized medium condition. The effect of incubation period for protease production is significant as per ANOVA test at $\mathrm{p}<0.01$. The $\mathrm{t}$-stat shows a significant difference between their population mean at 0.01 probability level.

\section{Discussion}

Present study investigated on protease production in cold temperature conditions. Therefore, cold temperature bacterial isolates were isolated from sediment samples of Nella Lake and screened primarily on skim milk agar plates and then the potential isolates were selected on the basis of the zone of clearances followed by quantitative assay using submerged fermentation technique. The potential isolate was identified as Pseudomonas gessardii strain N-86 having GenBank accession no. KY783362. It is a Gram -ve bacterial and psychrotolerant in nature. There are very few reports on Pseudomonas gessardii strains. Among them many researches were focused on lipase production (Ramani et al., 2010; Ramani and Sekaran, 2012; Veerapagu et al., 2013; von Neubeck et al., 2017). A research was found on Pseudomonas gessardii DSM $17152^{\mathrm{T}}$ isolated from bovine raw milk which showed proteolysis at $4^{\circ} \mathrm{C}$ on plate assay, while it showed negative at $25^{\circ} \mathrm{C}$ (von Neubeck et al., 2017) which is contradicting with our results having wide range of temperature tolerance capacity of studied Pseudomonas gessardii strains N-86. The same pattern of getting protease positive at both $5^{\circ} \mathrm{C}$ and $25^{\circ} \mathrm{C}$ was observed by Caldera et al., (2016). Besides, there are some reports available on cold active protease production by Pseudomonas spp. but it was limited to primary screening only (Hamamoto et al., 1994; Baghel et al., 2005; Maharana and Ray, 2013). Zeng et al., (2003) reported on a psychrophilic Pseudomonas strain DY-A isolated from deep sea produces cold active serine alkaline proteases at $10^{\circ} \mathrm{C}$. A psychrophilic strain Pseudomonas TAC II 18 was isolated from frozen vegetables abandoned for 40 years at the fire destroyed Antarctic station Port Martin in Terre Adelie, showed maximum protease production at $4^{\circ} \mathrm{C}$ than $25^{\circ} \mathrm{C}$ (Chessa et al., 2000). Shivaji et al., (2011) reported on Pseudomonas gessardii CIP $105469^{\mathrm{T}}$ isolated from sediment sample of fresh water lake situated at Schirmacher Oasis, Queen Maud Land, Antarctica, which showed negative for protease production at $4^{\circ} \mathrm{C}$.

Effects of various physical and chemical parameters were considered for optimize protease production by the strain N-86. 
Incubation temperature is not only necessary for the growth of a micro-organism but it also induces the microbes to produce respective hydrolytic enzymes for the utilization of substrates efficiently for survival (Maharana and Singh, 2018a). Low temperature regarded as an extreme environment and present study was focused on isolation of cold active protease. Therefore, protease production was investigated from $5^{\circ} \mathrm{C}$ to $45^{\circ} \mathrm{C}$. As depicted in Figure 4, optimum temperature is $15^{\circ} \mathrm{C}$ and the production is more at lower temperature than the higher ranges; therefore, it can be regarded as cold active protease having maximal activity towards low temperature which may have potential application to various industrial sectors. In contrary, psychrotrophic Pseudomonas spp. were isolated from Blue-green Algal Mats of Schirmacher Oasis, Antarctica having optimum temperature as $30^{\circ} \mathrm{C}$ for protease production (Singh and Ramana, 1998).

From Figure 5 one can conclude that the protease production is more in alkaline condition (optimum is at $9.5 \mathrm{pH}$ ) than acidic ranges which denotes alkalinity nature of the strain N-86 and its protease. This cold tolerant alkaline protease can be used in various food and detergent industries. While in contrary, Singh and Ramana, (1998) isolated Pseudomonas spp. from Schirmacher Oasis, Antarctica, which showed pH 7.0 as optimum for protease production. The effect of substrate concentrations is a crucial parameter for enzyme production which is depicted in Figure 6. An appropriate amount of substrate in a production medium not only will be utilized by the concerned microorganisms for their growth but also it can help to enhance the enzyme production effectively (Maharana and Singh, 2018c). A concentration of $2 \%$ $(w / v)$ of skim milk was regarded as optimum for protease production by the strain $\mathrm{N}-86$. After that protease production decreases due to increase in viscosity of the production medium which in turn reduces the effective circulation of nutrients and oxygen (Dhume et al., 2019).

Additional carbon and mineral sources and some amount of amino acids may enhance the enzyme production capacity of a bacterial isolate by giving additional nutrients to the microorganisms for growth which in-turn enhance the enzyme production in same proportion (Maharana and Singh, 2018c). Singh and Ramana, (1998) isolated psychrotrophic Pseudomonas spp. from Antarctica, which was assessed for hydrolytic enzymes including proteases. They reported best carbon sources for protease production at $15^{\circ} \mathrm{C}$ were Lactose and Maltose while in contrary showing optimum with $1 \%$ (w/v) Sucrose (Fig. 7). Carbon sources are not having the direct stimulating effects on enzyme production besides, giving an additional nutrients for the microorganisms for growth which successively increase the enzyme production in same ratio (Maharana and Singh, 2018a). Among 20 amino acids, maximum production of protease is found in production medium having $0.01 \%$ (w/v) $L$ Glutamine (Fig. 8). Reduction in enzyme activity by the other amino acids was presumably due to non-utilization or inhibitory effects of the amino acids on the growth of strain N-86 and, as the growth is retarded, so is the activity (Maharana and Ray, 2015b). Mineral salts are required for microbial growth and other activities. $\mathrm{MgCl}_{2}$ shows maximum protease activity w.r.t. control as depicted in Figure 9. Chlorides of Cobalt and Mercury drastically minimized protease production by strain N-86.

Initial inoculum concentration in a production medium plays an essential role in enzyme production by controlling the growth of a microbe. Small inoculum size controls and shortens the initial lag phase whereas larger inoculum size increases the duration of lag 
phase (Singh et al., 2012a). Maximum protease production was showed using $10 \%$ (v/v) of inoculum of strain N-86 (Fig. 10) and a sharp fall was observed at $20 \%$ of the same. After that a final production was conducted using all the optimized parameters for final production which showed maximum protease production was found at $15^{\circ} \mathrm{C}$ using Pseudomonas gessardii strain N-86 on $72 \mathrm{~h}$. At initial stage of production, a gradual increase in the protease production was experienced which was due to the abundant nutrients and no growth inhibitors. But after $72 \mathrm{~h}$ there was a slight fall of protease production which might be due to the depletion of nutrients, accumulation of toxic end products and the change in $\mathrm{pH}$ of the medium. Table 1 depicts the comparisons between the initial production medium with optimized medium conditions.

Table.1 Comparison between initial un-optimized medium conditions w.r.t. final optimized conditions for production of cold active protease

\begin{tabular}{|c|c|c|}
\hline $\begin{array}{c}\text { Parameters \& Chemical } \\
\text { composition }\end{array}$ & $\begin{array}{l}\text { Optimized conditions } \\
\text { (Strain N-86) }\end{array}$ & Un-optimized conditions \\
\hline Substrate, skim milk (w/v) & $2 \%$ & $1 \%$ \\
\hline $\mathrm{NaCl}(\mathbf{w} / \mathrm{v})$ & $0.2 \%$ & $0.2 \%$ \\
\hline $\mathrm{CaCl}_{2}(\mathrm{w} / \mathrm{v})$ & $0.01 \%$ & $0.01 \%$ \\
\hline $\mathrm{MgSO}_{4}(\mathrm{w} / \mathrm{v})$ & $0.04 \%$ & $0.04 \%$ \\
\hline $\mathrm{K}_{2} \mathrm{HPO}_{4}(\mathrm{w} / \mathrm{v})$ & $0.03 \%$ & $0.03 \%$ \\
\hline $\mathrm{KH}_{2} \mathrm{PO}_{4}(\mathrm{w} / \mathrm{v})$ & $0.03 \%$ & $0.03 \%$ \\
\hline $\mathrm{NH}_{4} \mathrm{SO}_{4}(\mathrm{w} / \mathrm{v})$ & $0.05 \%$ & $0.05 \%$ \\
\hline pH & 9.5 & 7.5 \\
\hline Inoculum size (v/v) & $10 \%$ & $5 \%$ \\
\hline Nitrogen source $(1 \%$ w/v $)$ & - & - \\
\hline Carbon source $(1 \%$ w/v) & Sucrose & - \\
\hline Minerals (0.1\% w/v) & $\mathrm{MgCl}_{2}$ & - \\
\hline Amino-acid $(0.01 \%$ w/v $)$ & $L$-Glutamine & - \\
\hline Incubation temperature $\left({ }^{\circ} \mathbf{C}\right)$ & 15 & 15 \\
\hline Incubation period (h) & 72 & 48 \\
\hline Protease $(\mathrm{U} / \mathrm{ml})$ & 1.414 & 0.261 \\
\hline FOLD INCREASE & \multicolumn{2}{|c|}{5.42} \\
\hline
\end{tabular}
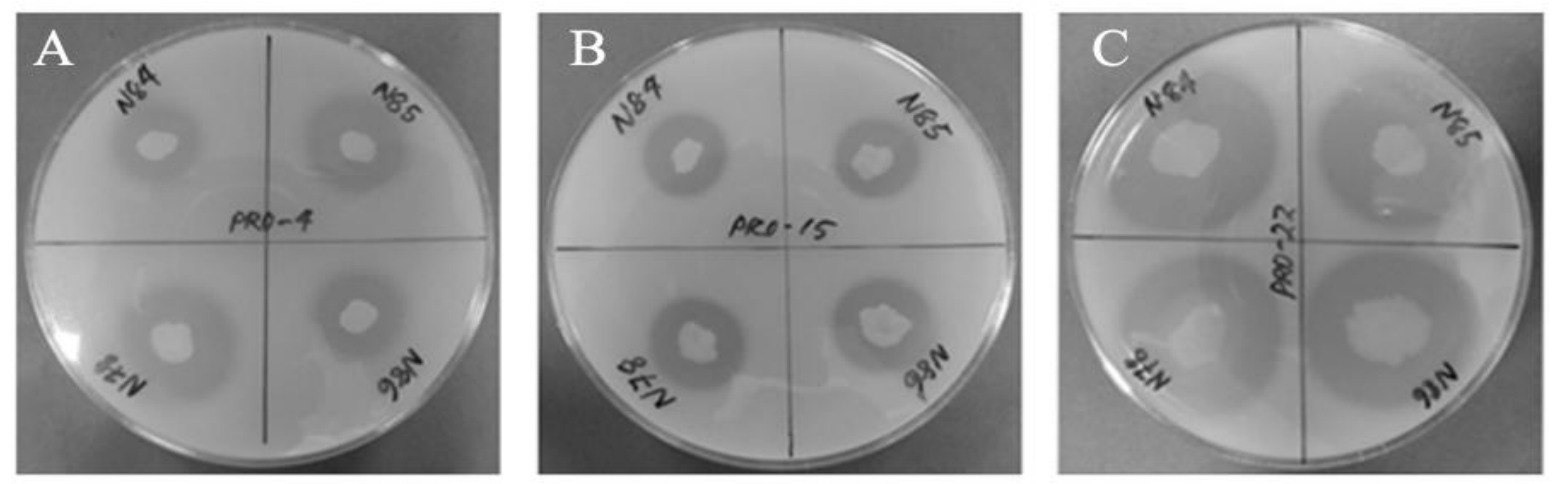

Fig.1 Qualitative plate assay of some Nella lake bacterial isolates for protease using skim milk agar (A) $4{ }^{\circ} \mathrm{C}$, (B) $15^{\circ} \mathrm{C}$ and (C) $22{ }^{\circ} \mathrm{C}$ 


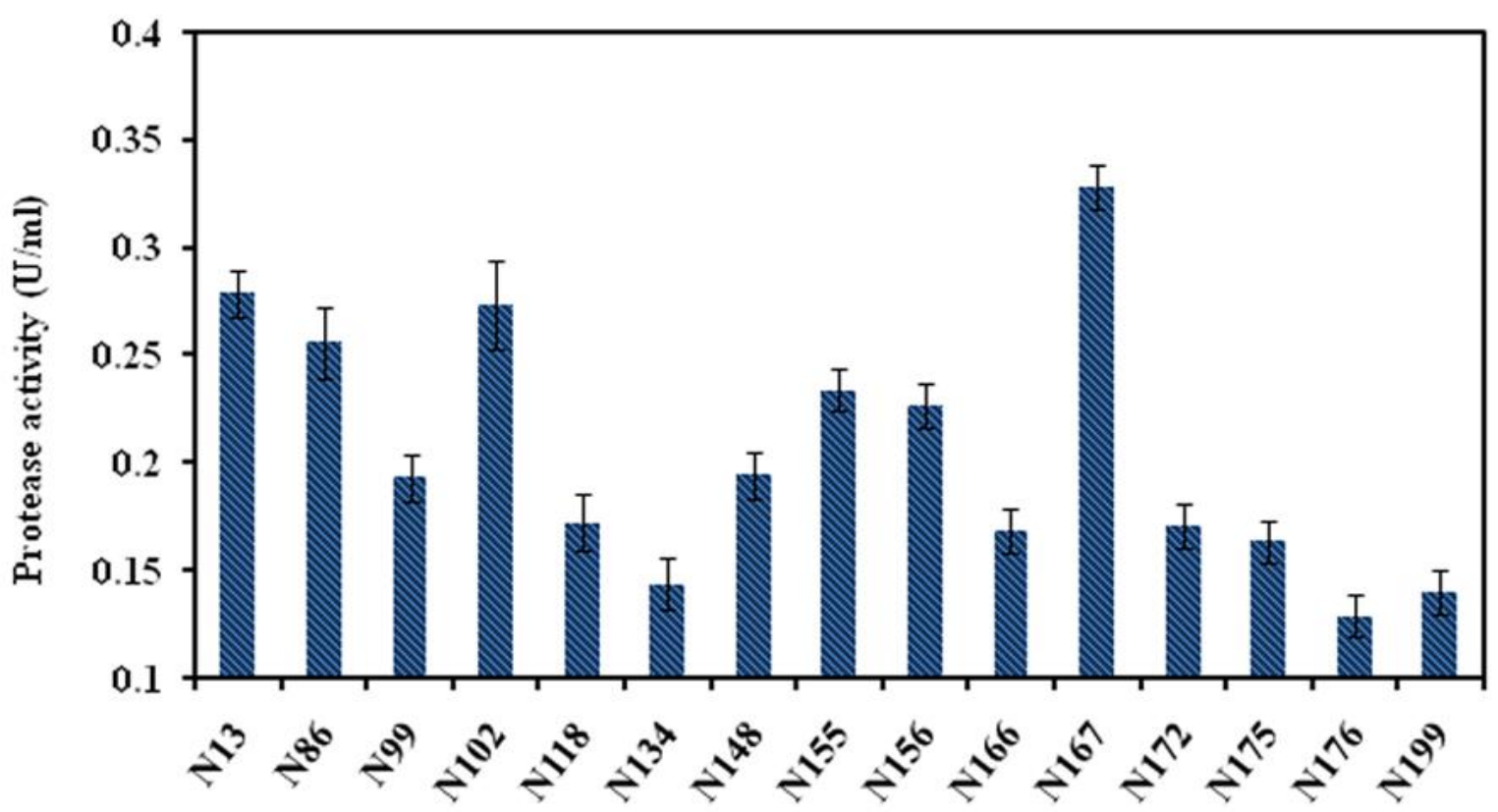

Bacterial isolates

Fig.2 Cold active protease production using 15 potential bacterial isolates at $15^{\circ} \mathrm{C}$ using casein as substrate incubated for $48 \mathrm{~h}$.

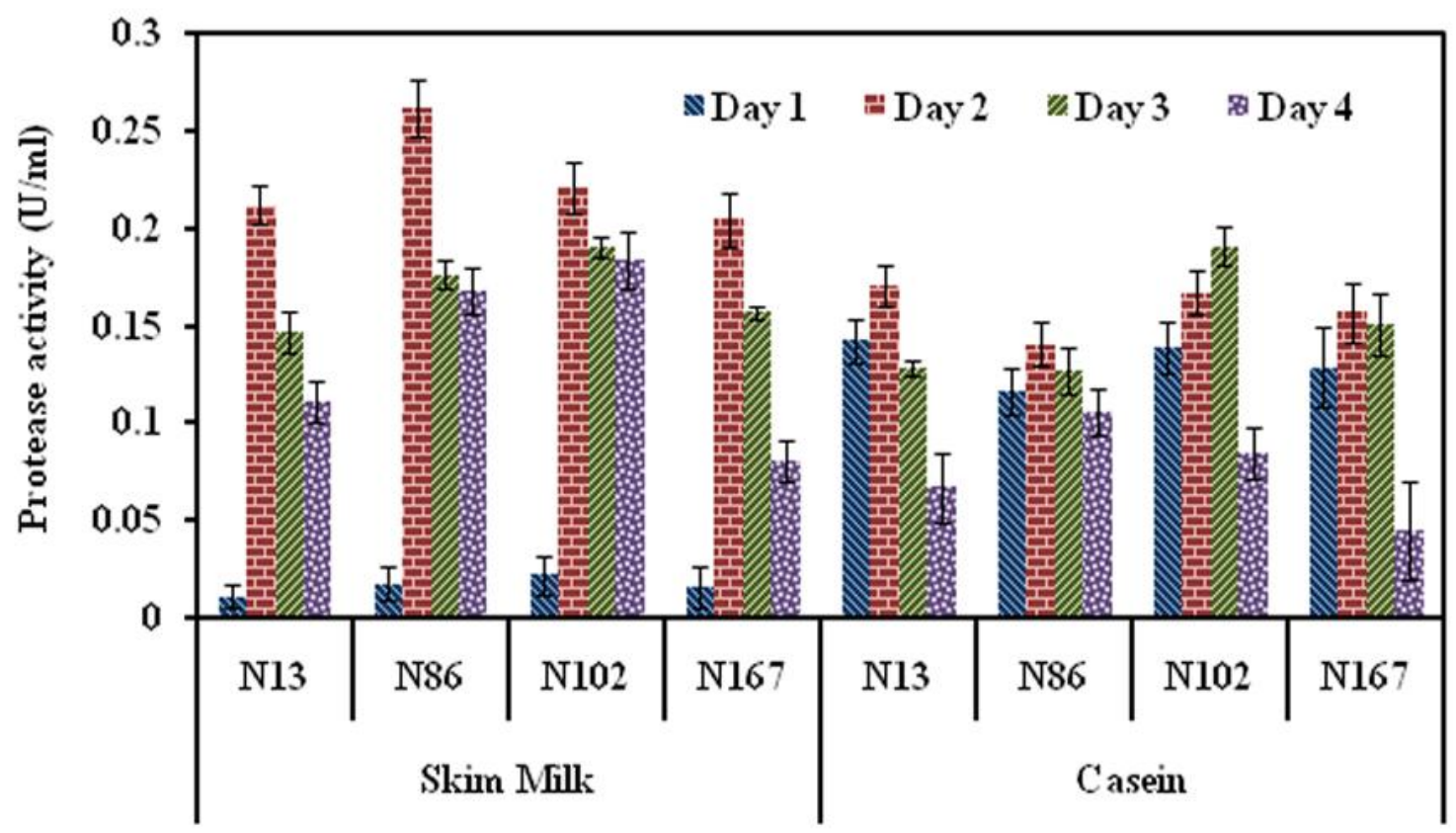

\section{Bacterial isolates}

Fig.3 Day-wise cold active protease production using best 4 bacterial isolates using various substrates at $15^{\circ} \mathrm{C}$ 


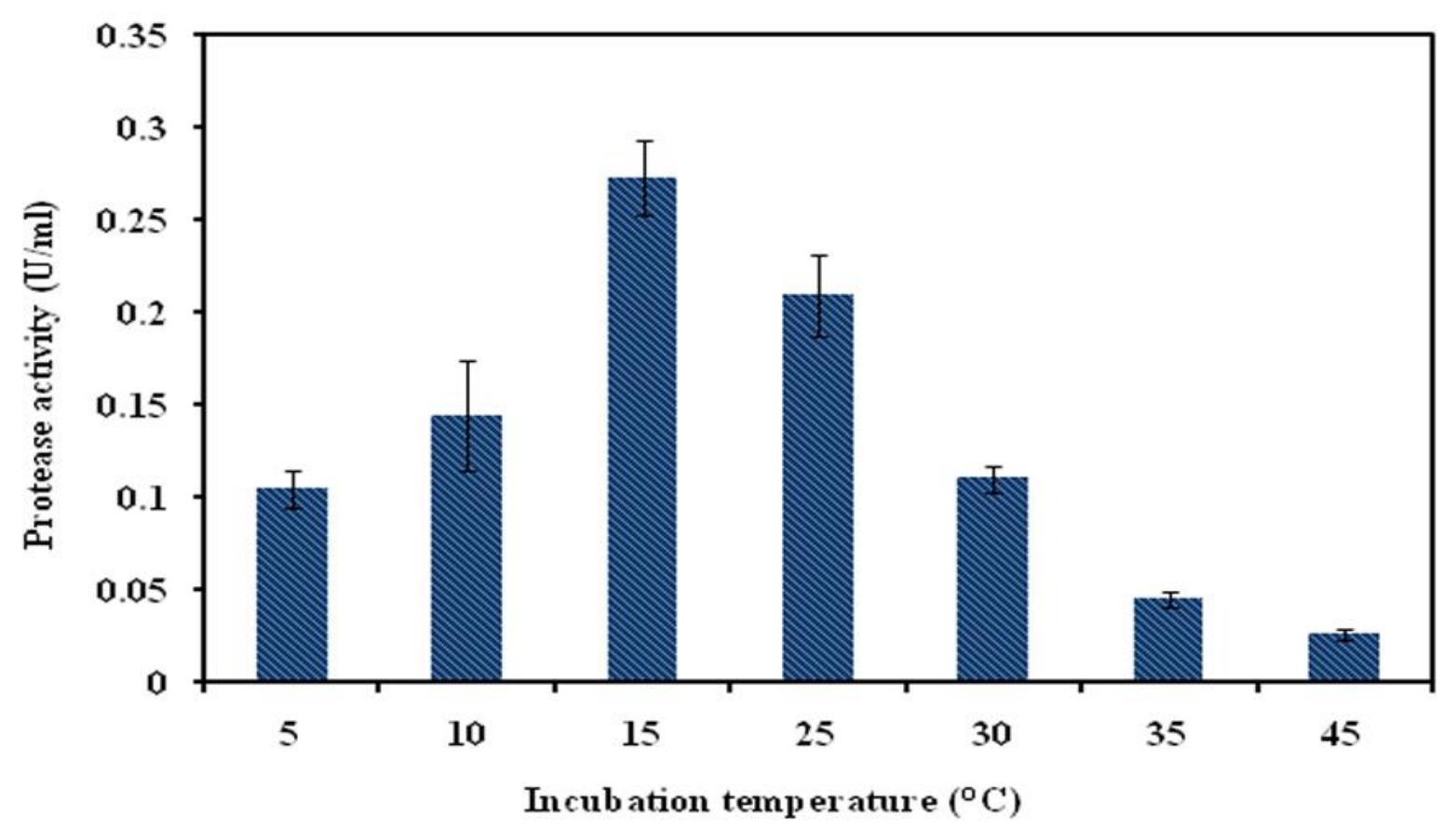

Fig.4 Effects of various incubation temperatures on cold active protease production by strain N-86. The results are the means of 3 independent experiments and the bars correspond to standard errors

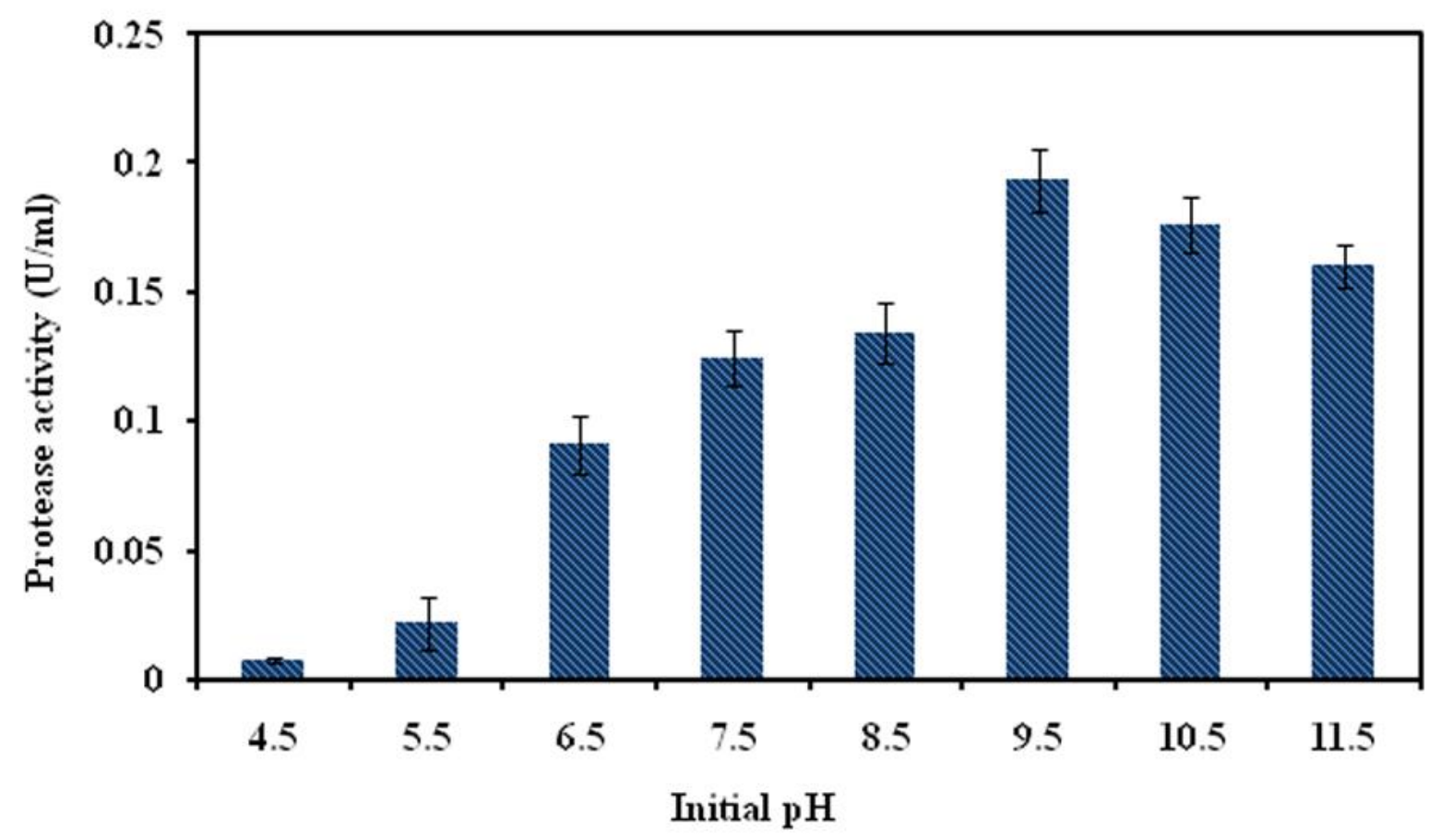

Fig.5 Effects of initial $\mathrm{pH}$ of the medium on cold active protease production by strain $\mathrm{N}-86$ at $15^{\circ} \mathrm{C}$. The results are the means of 3 independent experiments and the bars correspond to standard errors 


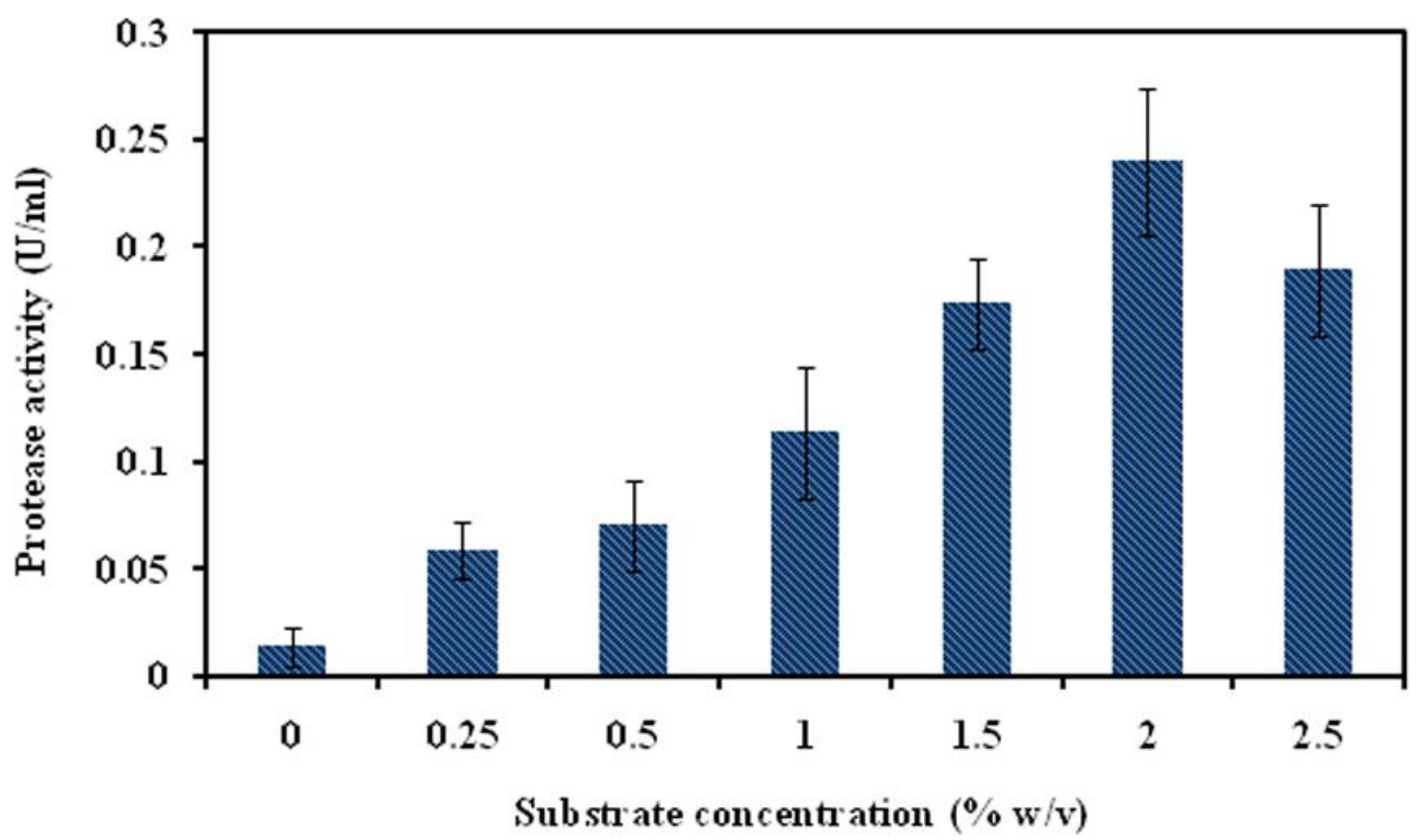

Fig.6 Effects of substrate concentrations on cold active protease production by strain $\mathrm{N}-86$ at $15^{\circ} \mathrm{C}$. The results are the means of 3 independent experiments and the bars correspond to standard errors

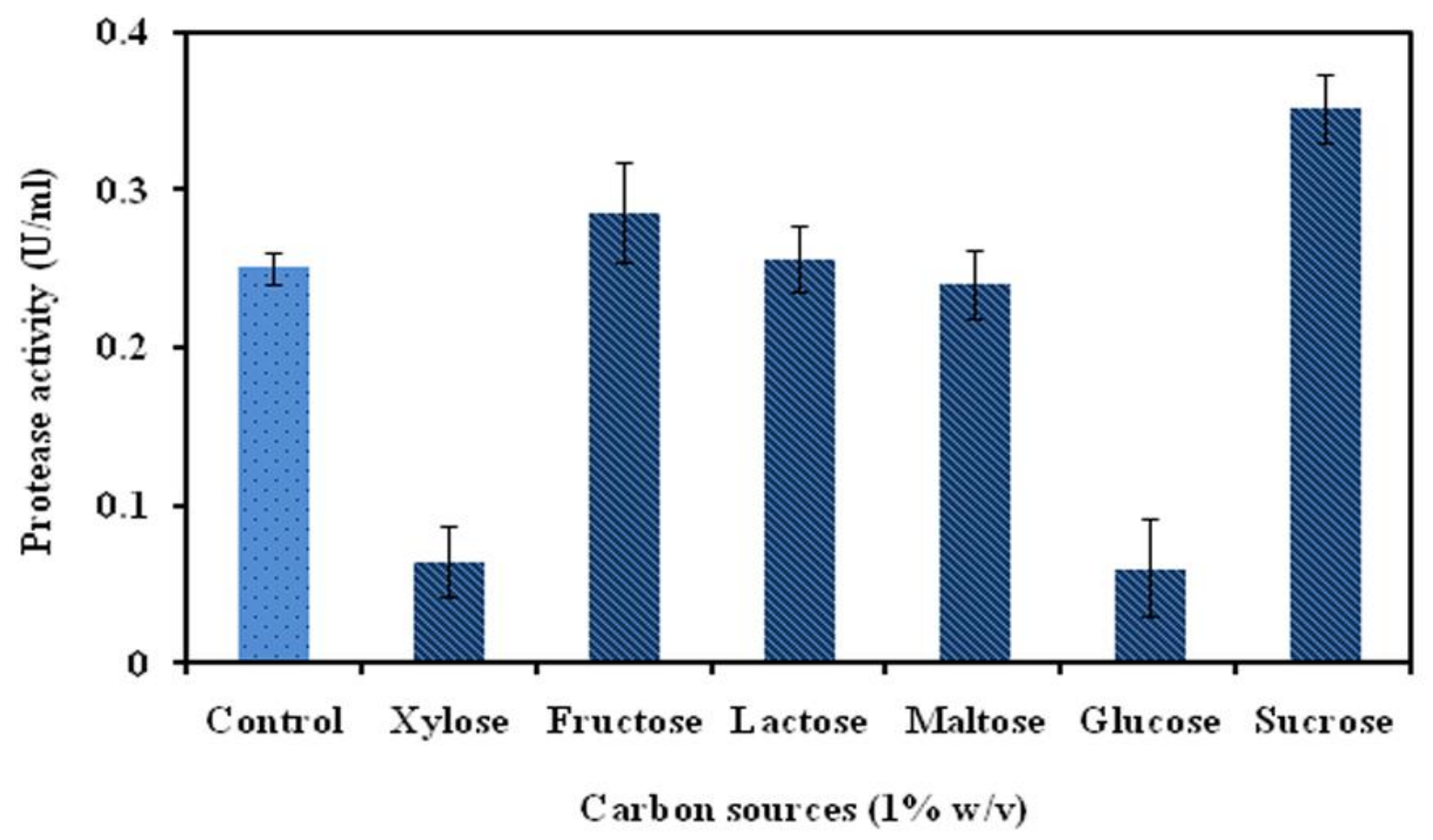

Fig.7 Effects of carbon sources on cold active protease production by strain $\mathrm{N}-86$ at $15^{\circ} \mathrm{C}$. Control medium is devoid of any additional carbon sources. The results are the means of 3 independent experiments and the bars correspond to standard errors 


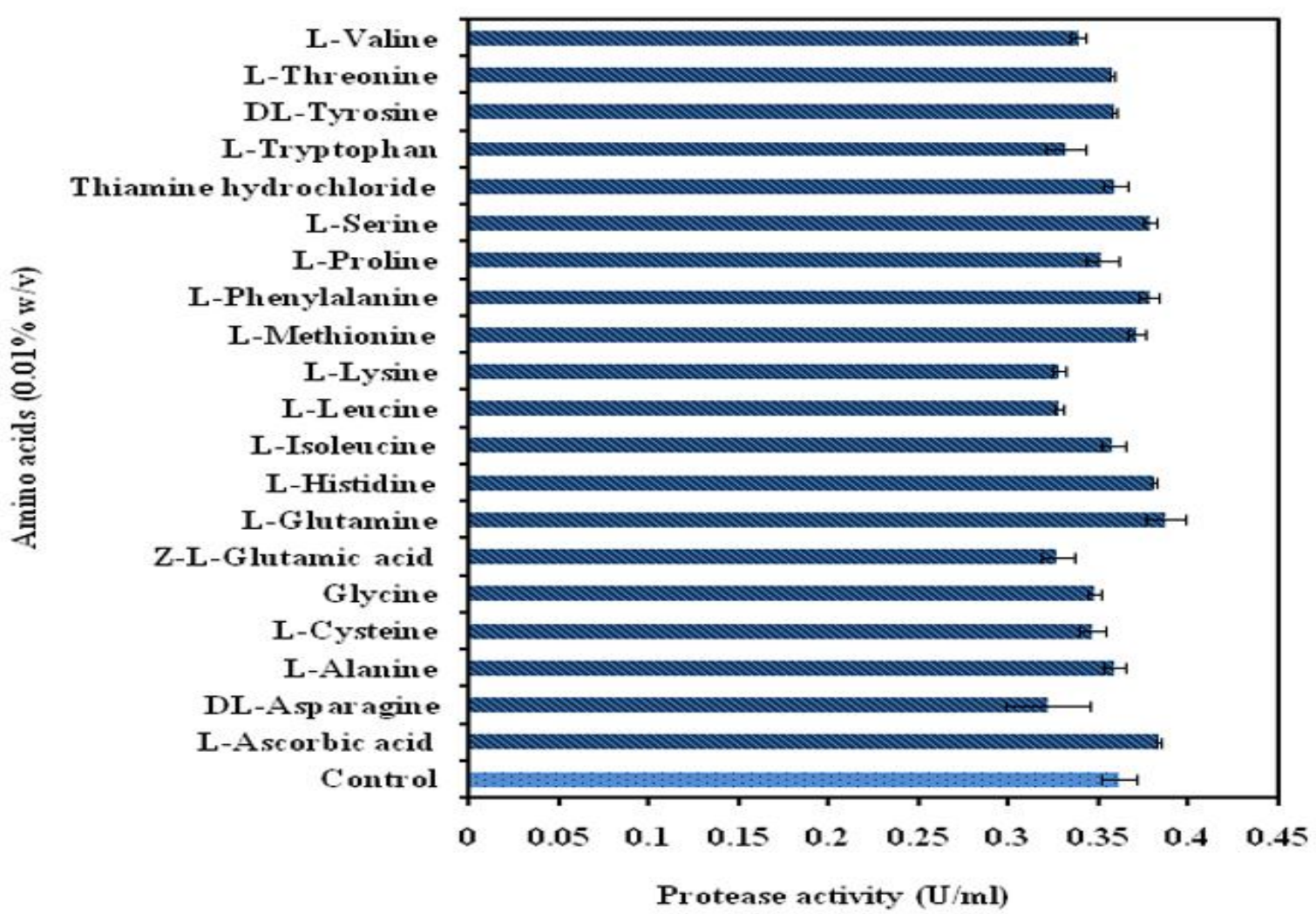

Fig.8 Effects of amino-acids on cold active protease production by strain $\mathrm{N}-86$ at $15^{\circ} \mathrm{C}$. Control medium is devoid of any additional amino acids. The results are the means of 3 independent experiments and the bars correspond to standard errors

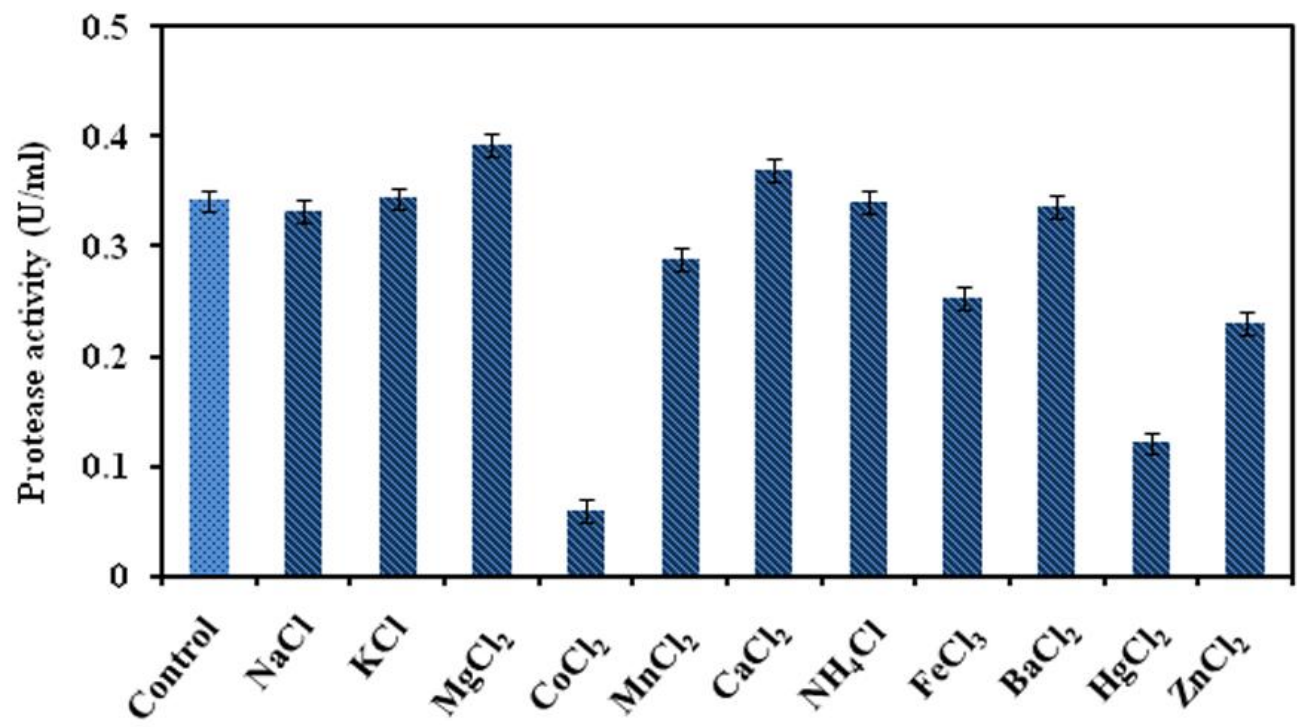

Miner al chlorides $(0.1 \% \mathrm{w} / \mathrm{v})$

Fig.9 Effects of mineral chlorides on cold active protease production by strain $\mathrm{N}-86$ at $15^{\circ} \mathrm{C}$. Control medium is devoid of any additional minerals. The results are the means of 3 independent experiments and the bars correspond to standard errors 


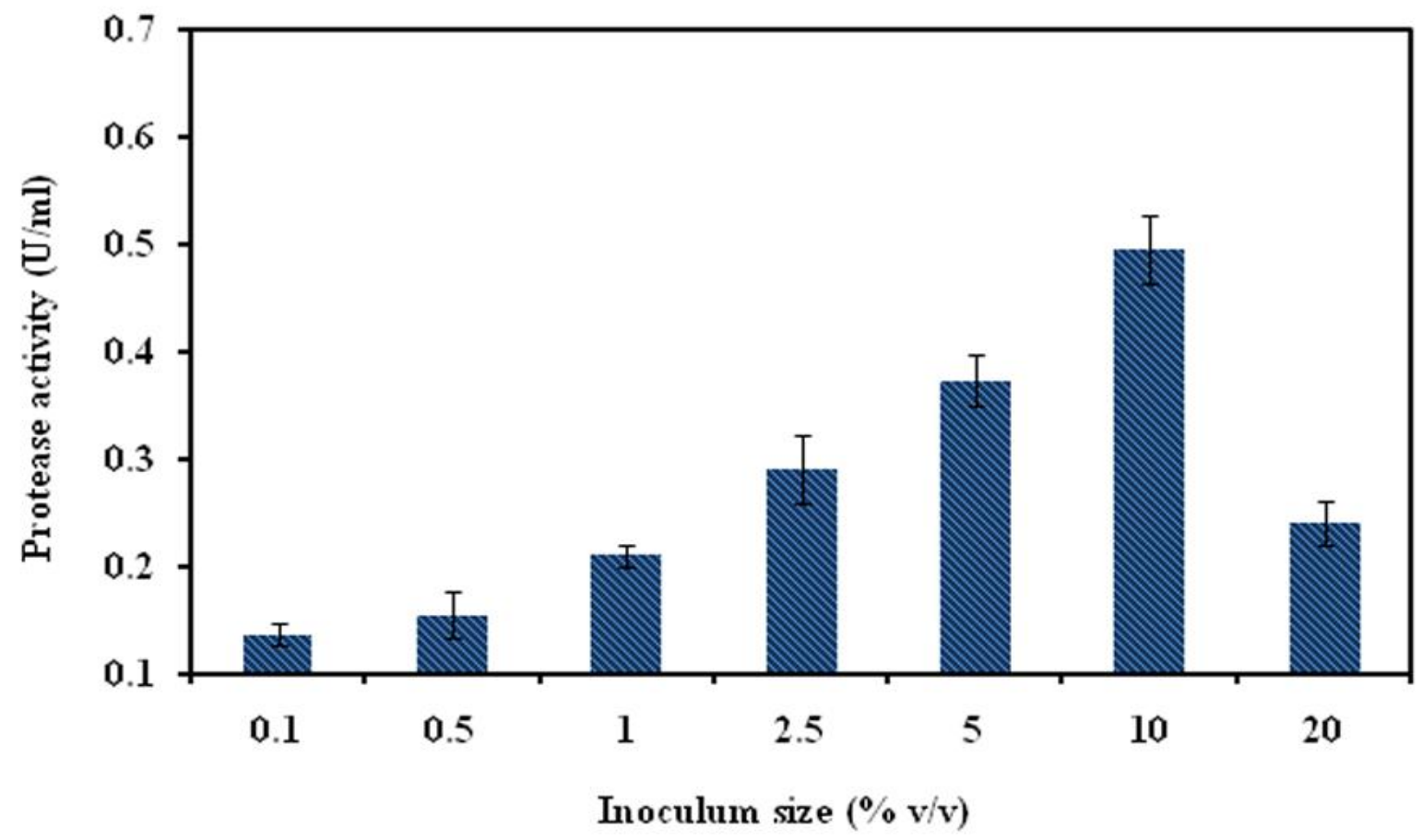

Fig.10 Effects of inoculum sizes on cold active protease production by strain $\mathrm{N}-86$ at $15^{\circ} \mathrm{C}$. The results are the means of 3 independent experiments and the bars correspond to standard errors

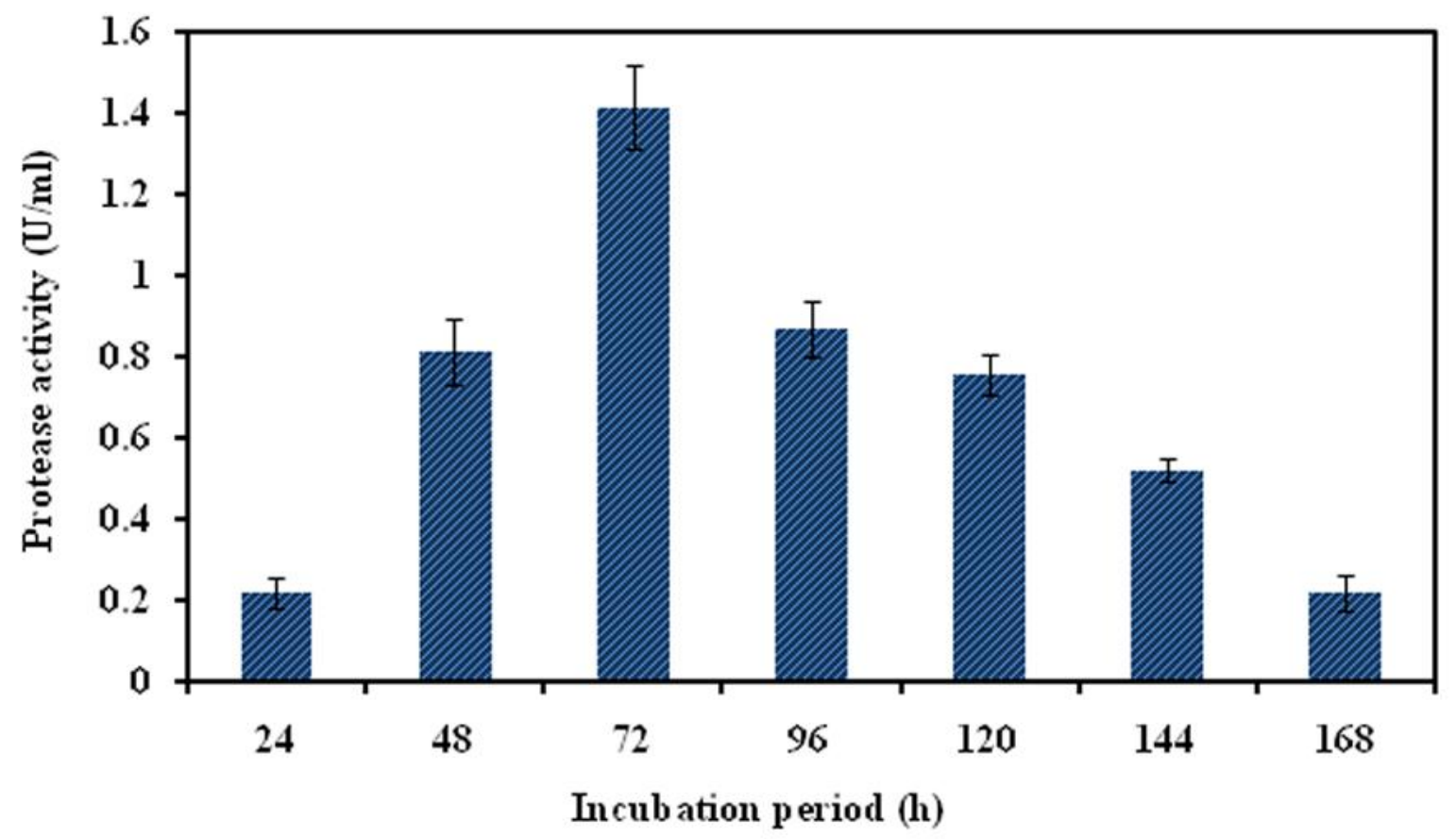

Fig.11 Effects of incubation period on cold active protease production by strain $\mathrm{N}-86$ at $15^{\circ} \mathrm{C}$. The results are the means of 3 independent experiments and the bars correspond to standard errors 
In summary, the present study successfully optimized the production medium enhancing the protease production effectively from unoptimized conditions, which confirmed from the fold increase in protease by 5.42 using Pseudomonas gessardii strain N-86.

Besides, to the best of our knowledge, our study is the first report on Pseudomonas gessardii isolated from Nella Lake, Antarctica producing cold active protease. Therefore, protease produced from above cold tolerant microorganisms can be used in various fields of science like detergent formulation for cold temperature washing of clothes and protein contaminants removal from waste water in cold and temperate regions due to their alkaline and cold tolerance capabilities.

Presently studied cold active protease may provide new insights into the potential biotechnological applications of the isolate in Antarctic environments.

\section{Acknowledgements}

This study was financed by institutional project "Microbial Diversity of Antarctica" at National Centre for Antarctic \& Ocean Research, Vasco-da-Gama, Goa, India. Authors are grateful to the Director, NCAOR, Goa, for facilities and Dr. G.S. Prasad, Chief Scientist, Institute of Microbial Technology, Chandigarh for molecular identification of isolate. This research was funded by Ministry of Earth Sciences, National Center for Antarctic and Ocean Research.

\section{References}

Baghel, V. S., R. D. Tripathi, P. W. Ramteke, K. Gopal, S. Dwivedi, R. K. Jain, U. N. Rai and Singh, S. N. 2005. Psychrotrophic proteolytic bacteria from cold environment of Gangotri glacier, Western Himalaya, India. Enzyme Microb. Technol. 36, 654-659.
Caldera, L., L. V. Franzetti, E. V. Coillie, P. D. Vos, P. Stragier, J. D. Block and Heyndrickx, M. 2016. Identification, enzymatic spoilage characterization and proteolytic activity quantification of Pseudomonas spp. isolated from different foods. Food Microbial. 54, 142-153.

Chessa, J. P., I. Petrescu, M. Bentahir, J. V. Beeumen and Gerday, C. 2000. Purification, physico-chemical characterization and sequence of a heat labile alkaline metalloprotease isolated from a psychrophilic Pseudomonas species. Biochimica. et. Biophysica. Acta. 1479(1-2): 265-274.

Dhume, G. M., A. K. Maharana, M. Tsuji, A. K. Srivastava and Singh, S. M. 2019. Cold- tolerant endoglucanase producing ability of Mrakia robertii A2- 3 isolated from cryoconites, Hamtha glacier, Himalaya. J. Basic Microbial. 59(7): 667679.

Gao, X-G., S-G. Cao and Zhang, K-C. 2000. Production, properties and application to non-aqueous enzymatic catalysis of lipase from a newly isolated Pseudomonas strain. Enzyme Microb. Tech. 27, 74-82.

Hamamoto, T., M. Kaneda, K. Horikoshi and Kudo, T. 1994. Characterization of protease from a psychrotroph, Pseudomanas fluorescenes 114. Appl. Environ. Microbiol. 60(10): 3878-3880.

Huang, H., K. Wu, A. Khan, Y. Jiang, Z. Ling, P. Liu, Y. Chen, X. Tao and Li, X. 2016. A novel Pseudomonas gessardii strain LZ-E simultaneously degrades naphthalene and reduces hexavalent chromium. Bioresour. Technol. 207, 370378.

Maharana A. K., 2016. Extracellular cold active endoglucanase and pigment producing psychrotolerant Penicillium Pinophilum. Int. J. Pharm. Pharm. Sci. 8(10): 164-169.

Maharana A.K., I. Sinha, P. C. Behera and Ray, P. 2016. Extracellular alkaline protease producing halo-alkalitolerant bacteria isolated from marine coasts of Odisha. Int. J. Pharm. Pharm. Sci. 8(5): 379-386.

Maharana, A. and Ray, P. 2015a. A novel cold- 
active lipase from psychrotolerant Pseudomonas sp. AKM-L5 showed organic solvent resistant and suitable for detergent formulation. J. Mol. Cata. B: Enzym. 120, 173-178.

Maharana, A. K. and Ray, P. 2013. Isolation and screening of cold active extracellular enzymes producing psychrotrophic bacteria from soil of Jammu City. Biosci. Biotechnol. Res. Asia. 10(1): 267-273.

Maharana, A. K. and Ray, P. 2014a. Low temperature degradation of various substrates by psychrotolerant Fusarium spp. isolated from soil of Jammu city. J. Adv. Microbiol. 1(1): 52- 56.

Maharana, A. K. and Ray, P. 2014b. Screening of psychrotrophic micro-fungi for cold active extracellular enzymes isolated from Jammu city, India. J. Pure Appl. Microbiol. 8(3): 2369-2375.

Maharana, A. K. and Singh, S. M. 2018a. A cold and organic solvent tolerant lipase produced by Antarctic strain Rhodotorula sp. Y- 23. J. Basic Microbiol. 58(4): 331342.

Maharana, A. K., and Ray, P. 2014c. Application of Plackett-Burman Design for improved cold temperature production of lipase by psychrotolerant Pseudomonas sp. AKM-L5. Int. J. Curr. Microbiol. Appl. Sci. 3(4): 269-282.

Maharana, A. K., and Ray, P. 2015b. Optimization and characterization of cold active endoglucanase produced by Aspergillus terreus strain AKM-F3 grown on sugarcane bagasse. Turk. J. Biol. 39, 175-185.

Maharana, A. K., and Singh, S. M. 2018b. Cold active amylases producing psychrotolerants isolated from Nella Lake, Antarctica. Biosci. Biotechnol. Res. Asia 15(1): 5-16.

Maharana, A. K., and Singh, S. M. 2018c. Cold active lipases produced by Cryptococcus sp. Y-32 and Rhodococcus erythropolis N149 isolated from Nella Lake, Antarctica. Int. J. Curr. Microbiol. App. Sci 7(3): 1910-1926.

Matsui, M., A. Kawamata, M. Kosugi, S. Imura, and Kurosawa, N. 2017. Diversity of proteolytic microbes isolated from Antarctic freshwater lakes and characteristics of their cold-active proteases. Polar Sci. 13, 82-90.

Park, H. J., Y. M. Lee, S. Kim, A. R. Wi, S. J. Han, H. W. Kim, I. C. Kim, J. H. Yim and Kim, D. 2014. Identification of proteolytic bacteria from the Arctic Chukchi Sea expedition cruise and characterization of cold-active proteases. J. Microbiol. 52, 825-833.

Ramani, K., and Sekaran, G. 2012. Production of lipase from Pseudomonas gessardii using blood tissue lipid and thereof for the hydrolysis of blood cholesterol and triglycerides and lysis of red blood cells. Bioproc. Biosyst. Eng. 35(6): 885-896.

Ramani, K., E. Chockalingam, and Sekaran, G. 2010. Production of a novel extracellular acidic lipase from Pseudomonas gessardii using slaughterhouse waste as a substrate. J. Ind. Microbiol. Biot. 37(5): 531-535.

Rashid, N., S. Yuji, E. Satoshi, A. Haruyuki and Tadayuki, I. 2001. Low temperature lipase from psychrotrophic Pseudomonas sp. Strain KB700A. Appl. Environ. Microbiol. 67, 4064-4069.

Reddy, P. V. V., S. S. S. N., Rao, M. S., Pratibha, B., Sailaja, B., Kavya, R. R., Manorama, S. M., Singh, T. N. R. Srinivas and Shivaji, S. 2009. Bacterial diversity and bio-prospecting for coldactive enzymes from culturable bacteria associated with sediment from a melt water stream of Midtre Lov' enbreen glacier, an Arctic glacier. Res. Microbiol. 160(8): 538-546.

Sen, S., B. Mandal and Dasu, V. V. 2009. Alkaline Protease: a tool to clean environment. In: AIChE Spring National Meeting.

Shivaji, S., K. Kumari, K. H. Kishore, P. K. Pindi, P. S. Rao, T. N. R. Srinivas, R. Asthana, and Ravindra, R. 2011. Vertical distribution of bacteria in a lake sediment from Antarctica by culture-independent and culture-dependent approaches. Res. Microbiol. 162(2): 191-203. 
Singh, A. K., A. K. Maharana, H. Masih, Y. Kumar and Mishra, S. K. 2012a. Production, optimization and purification of bacterial cellulase by solid-state bioprocessing of agro biomass. Res. J. Pharm. Biol. Chem. Sci. 3(2): 977-989.

Singh, L. and Ramana, K. V. 1998. Isolation and characterization of psychrotrophic Antarctic bacteria from blue-green algal mats and their hydrolytic enzymes. Fourteenth Indian Expedition to Antarctica, Scientific Report, Department of Ocean Development, Technical Publication No. 12, pp 199-206.

Singh, P., S. M. Singh and Dhakephalkar, P. 2014. Diversity, cold active enzymes and adaptation strategies of bacteria inhabiting glacier cryoconite holes of High Arctic. Extremophiles.18(2): 229242.

Singh, P., S. M. Singh and Roy, U. 2016. Taxonomic characterization and the bio- potential of bacteria isolated from glacier ice cores in the High Arctic. J. Basic Microbial. 56(3): 275-285.

Singh, S. M., A. K. Maharana and Naik, S. 2017. Microbial communities of Nella Lake, Larsemann Hills, East Antarctica. In: Anton Van de Putte (Ed.), Book of Abstracts, XIIth SCAR Biology Symposium. Leuven, Belgium, Scientific Committee on Antarctic Research (SCAR), Cambridge, United Kingdom.
Pp. 512.

Singh, S. M., S. K. Singh, L. S. Yadav, P. N. Singh and Ravindra, R. 2012b. Filamentous soil fungi from $\mathrm{Ny}$-Ålesund, Spitsbergen, and screening for extracellular enzymes. Arctic. 45-55.

Vazquez, S. C., and Mac Cormack, W. P. 2002. Effect of isolation temperature on the characteristics of extracellular proteases produced by Antarctic bacteria. Polar Res. 21(1): 63-72.

Veerapagu, M., A. S. Narayanan, K. Ponmurugan, and Jeya, K. R. 2013. Screening selection identification production and optimization of bacterial lipase from oil spilled soil. Asian J. Pharm. Clin. Res. 6(3): 62-67.

von Neubeck, M., C. Huptas, C. Glück, M. Krewinkel, M. Stoeckel, T. Stressler, L. Fischer, J. Hinrichs, S. Scherer and Wenning, M. 2017. Pseudomonas lactis sp. nov. and Pseudomonas paralactis sp. nov., isolated from bovine raw milk. Int. J. Syst. Evol. Microbiol. 67(6): 16561664.

Zeng, R., R. Zhang, J. Zhao and Lin, N. 2003. Cold-active serine alkaline protease from the psychrophilic bacterium Pseudomonas strain DY-A: enzyme purification and characterization. Extremophiles. 7(4): 335-337.

\section{How to cite this article:}

Abhas Kumar Maharana and Shiv Mohan Singh. 2020. Extracellular Cold Active Alkaline Proteolytic Enzyme Produced by Pseudomonas gessardii Strain N-86 Isolated from Antarctica. Int.J.Curr.Microbiol.App.Sci. 9(06): 3119-3134. doi: https://doi.org/10.20546/ijcmas.2020.906.374 